\title{
Influences of Youth Leadership within a Community-Based Context
}

\author{
Kenneth R. Jones \\ Assistant Professor \\ Department of Community and Leadership Development \\ 500 Garrigus Bldg. \\ University of Kentucky \\ Lexington, KY 40546-0215 \\ kenrjones@uky.edu
}

\begin{abstract}
This research project evaluated outcomes for a leadership development program utilizing adult volunteers who worked with youth to incorporate experiential learning and civic engagement opportunities. As a result, this experience exposed youth to practical skills as well as a chance to develop a sense of community connectedness. This was revealed through the youth developing more positive perceptions toward their role as decision makers in their communities, after participation in the program. Youth also developed more positive perceptions of their relationships with adults. Moreover, when comparing those youth who volunteer at least one hour per week to those who do not, those who had volunteered in the past had significantly more positive perceptions than those who had never volunteered in their community.
\end{abstract}

\section{Introduction}

In recent years much discourse has shaped the relevance in determining the role of youth leadership in community decision-making. Research has revealed that youth program activities, albeit consistently on the rise, engage youth in civic and community activities at rates that have been mediocre at best. In the 1990s the positive youth development movement was set forth by scholars and practitioners (Blythe \& Leffert, 1995; Cargo, Grams, Ottoson, Ward, \& Green, 2003; Lerner, 1995; Pittman, Irby, \& Ferber, 2000) which rallied the importance of all the resources and assets needed for a young person to experience a healthy, productive life. Then in recent years some of these scholars and practitioners noted that in order to maximize their potential young people need more than access to resources with means to build skills, but they must also utilize these skills by serving as active contributors within their communities (Hughes \& Curnan, 2000; Lerner, 2004, 2007; Pittman, 2000; Perkins, Borden, \& Villarruel, 2001). 
There has been a sporadic growth in the interest of youth becoming more involved in the communities in which they live. Although a growing body of literature has promoted youth leadership, there remains limited empirical evidence of how youth benefit from serving as civically-engaged leaders to address community issues. Most of the existing data is a result of qualitative procedures used to explore the youth-adult partnering phenomenon (Camino, 2000; Larson, Walker, \& Pearce, 2005). A few studies have found that youth develop leadership skills, social skills, and life skills (Checkoway, et al., 2003; Israel \& Ilvento, 1995; Lerner, Dowling, \& Anderson, 2003; Perkins \& Borden, 2003; Zeldin, McDaniel, Topitzes, \& Calvert, 2000) and communities also benefit from the endeavors set forth by such partnerships (Sandefur \& Laumann, 1998). However, more studies that take a longitudinal approach to investigating youth leadership development over time are needed.

While youth volunteerism has increased among 12-23 year olds, there is an argument that young people rarely engage with larger civic goals in mind (Case Foundation, 2006). Based on a study by the Center for Information and Research on Civic Learning and Engagement (CIRCLE), 59\% of young women ages 15-25 and $57 \%$ of young men were not actively engaged in community (civic or political) affairs (Marcelo, Lopez, \& Kirby, 2007). With the depth of human and social capital existing among them there must be more efforts in place to profit from the leadership potential among youth which often goes untapped.

As citizens youth have the right to make decisions on civic affairs that directly affect their lives (Camino, 2001). Organizations should take the opportunity to help youth create civic awareness that translates into a sense of community connectedness (Flanagan \& Van Horn, 2003; Checkoway, et al., 2003). As with most adults, young people favor being involved in organizations where they enjoy working with their peers and being able to witness that their participation made a difference (Lerner, 2004; Pancer, Rose-Krasnor, \& Hoiselle, 2002).

This study addressed the importance of youth having a civic leadership role within programs and community projects and how they can serve as a catalyst for empowering local residents through community-based initiatives. The goal of the projects was to support positive youth development by promoting leadership and civic engagement among youth. The study involved providing volunteer development training for approximately 60 adult leaders, who in turn coordinated leadership development experiences for 164 youth. 


\section{Theoretical Framework}

There remains a major assumption that in order to reach desired results of advancing community connectedness, youth must play a role in improving their communities. Out-of-school time is filled with promise and the opportunity to bring young people to the level where they can develop those skill sets that are pertinent for a citizen to be productive. From a preventive approach it is often seen as a time for leisure where young people are exposed and vulnerable to a plethora of risk factors (Villaruel \& Lerner, 1994). Perkins and Borden (2003) propitiously defined this time as any structured learning activity offered out of school and within programs where youth can serve their communities and connect with positive peers and adults. They further go on to discuss that high quality youth programs infuse reflective learning opportunities which aids youth in gaining an understanding of themselves and others. Jones (2006) also concluded that similar programs that engage youth and adults as decision-makers were more successful when the participants (i.e., youth and adults) were permitted to implement plans, evaluate progress, and rate the quality of their experiences. This supports the notion that just having positive attributes is not enough. Youth must be given the chance to develop those skills that undergird a civic-minded society. A rather advantageous way of ensuring this is by providing youth with the chance to have a role in their development. Hence, there remains a benefit in youth taking on leadership roles.

Youth development, at its core, involves participation of young people at some level to make the transition from childhood to adulthood. The duty of youth service providers is to insist that this experience is indeed an affirming one, thus perpetuating youth to levels of productive growth. Over the course of more than a decade positive youth development has been deemed the mantra for achieving desired developmental outcomes for youth. The phenomenon targets all of the practices, principles, resources, and assets in a community geared towards helping ensure young people have a chance to thrive while growing into healthy, responsible adults (Lerner, 2004; Pittman, Irby, \& Ferber, 2000). As a part of this movement, the Carnegie Corporation of New York released a report indicating the needs of adolescents (Carnegie Council on Adolescent Development, 1992). They included opportunities such as: (a) socializing with peers and adults, (b) developing skills that are relevant now and in the future, (c) contributing to the community, (d) belonging to a valued group, and (e) extending feelings of competency. All of these needs are identifiable as resources that make positive youth development attainable. Moreover, they are crucial in the development of youth leadership. Since the Carnegie report, a number of prominent youth serving organizations have presented program models that incorporate proactive means to enforce positive youth development principles and practices (Kress, 2004; Lerner, 2004; Search Institute, 1997; America's Promise, 2006). Table 1 lists four 
organizations and their means of quantifying positive youth development. Each of the principles is salient with critical skills needed to instill leadership within youth.

Table 1

Youth Serving Organizations with Foci on Leadership through Positive Youth Development

\begin{tabular}{|c|c|}
\hline $\begin{array}{l}\begin{array}{l}\text { Institute for Applied Research } \\
\text { in Youth Development } \\
\text { Tufts University }\end{array} \\
\text { Competence } \\
\text { Confidence } \\
\text { Connection } \\
\text { Caring/Compassion } \\
\text { Contribution } \\
\text { Source: Lerner, 2004, } 2007\end{array}$ & $\begin{array}{l}\text { 4-H Essential Elements } \\
\text { Belonging } \\
\text { Positive relationships with caring adults } \\
\text { A safe environment } \\
\text { Welcoming/inclusive environment } \\
\text { Generosity } \\
\text { Opportunity to value and practice } \\
\text { service } \\
\text { Independence } \\
\text { Opportunity for self-determination } \\
\text { Active participant in the future } \\
\text { Mastery } \\
\text { Opportunity for mastery } \\
\text { Engagement in learning }\end{array}$ \\
\hline $\begin{array}{l}\text { Search Institute's Asset Model } \\
\text { External Asset } \\
\text { Support } \\
\text { Empowerment } \\
\text { Boundaries and expectations } \\
\text { Constructive use of time } \\
\text { Internal Assets } \\
\text { Commitment to learning } \\
\text { Positive values } \\
\text { Social competencies } \\
\text { Positive identity } \\
\end{array}$ & $\begin{array}{l}\text { America's Promise } \\
\text { Caring adults } \\
\text { Safe places } \\
\text { Healthy start } \\
\text { Effective education } \\
\text { Opportunities to help others } \\
\text { Source: AmericasPromise.org }\end{array}$ \\
\hline
\end{tabular}

Note: ${ }^{1}$ Source: Kress (2004); ${ }^{2}$ Search Institute model consists of 40 assets (Only the categories in which these assets are grouped are listed in Table 1.)

The connection between youth involvement within communities and their involvement as adults have been well documented. Research studies have shown that young people who are civically engaged in their communities are more likely to serve as leaders during their college days and later in adulthood (Eccles \& Gootman, 2002; Flanagan, 1998; Youniss, McLellan, \& Yates, 1997). One valid reason youth desire to have leadership roles and contribute to their community is 
because it provides a sense of mattering and feeling of being able to make a difference (Eccles \& Gootman, 2002; Flanagan \& Van Horn, 2003). In turn, ethics serve as a by-product of service, a characteristic that is valued among all who recognize moral character and civic responsibility as a virtue of leadership. Moreover, service to the community can move young people beyond their idealistic worlds, thus allowing them to be empathetic to the needs of others. As a result, there is a sense of urgency to embrace the concept of being a leader. While many youth programs should be commended for the support they provide, several struggle with capitalizing on the intrinsic leadership abilities possessed by youth. There is often a focus on building skills instead of giving an opportunity to assess how much their leadership abilities have progressed within a given period of time. Youth should be seen as "experts" who are very much aware of what occurs among peers within their communities (Libby, Rosen, \& Sedonaen, 2005).

Their perspective on what young people need is invaluable and should be considered by those youth development specialists who have the task of planning programs. Accordingly, most of the youth participants are given opportunities to practice and refine those skills while building confidence and stronger positive relationships with peers (Libby, Rosen, \& Sedonaen, 2005). This intentional form of leadership development affords youth with the ability to overcome any hesitation to take on leadership roles. This is an initial stage in equipping one with what is needed to be an effective leader.

Evidence has also revealed the importance of adults providing critical support to youth so that young people have opportunities to hone in on their skills and are not beset by frustrations that may arise in the decision-making process. Jones \& Perkins (2006) conducted a study that examined perceptions and experiences of youth and adults engaged in five types of relationships with adults: (a) adultcentered leadership, (b) adult-led collaborations, (c) youth-adult partnerships, (d) youth-led collaborations, and (e) youth-centered leadership. The findings indicated that adult support was a critical component needed in all types of relationships, particularly in those where youth were serving as equal partners with adults or were leading community projects with minor adult supervision. When adult support was present, youth in youth-led collaborations were significantly more positive towards their ability to serve as leaders in communities.

Several theoretically-based qualitative assessments have been conducted to provide a basis for a new area of scholarship around various forms of youth-adult relationships. Camino (2000) identified specific concepts to assess approaches in identifying youth-adult partnerships such as youth having the opportunity to exercise decision-making power, their role in building strong communities, and the effect of adults' negative attitudes toward youth in community program activities. Teaching and learning between adults and youth were also viewed as 
crucial elements which distinguish youth-adult partnerships from traditional youth-adult relationships (e.g., parent-child, teacher-student, and mentoring). Kaplan (1997) also reported that through an action research study involving intergenerational community projects, youth learned "critical thinking skills, and developed a sense of citizenship responsibility" (p. 226). The work of these scholars along with others confirms that youth learn to be leaders by watching and working with those adults who have acquired life skills that young people need to develop. As an assurance that this will occur, positive youth-adult relationships must be created and sustained.

The purpose of this study was to describe how youth perceived their leadership roles within communities. The objectives of the study were to:

- Describe the demographic profile of participants,

- Determine changes in youth participants' perceptions toward their role as decision-makers,

- Determine changes in youth participants' perceptions toward their relationships with adults, and

- Provide recommendations as sources of information on how future research can assist youth programs in promoting leadership and civic engagement.

\section{Population}

This study utilized a purposive sample (Creswell, 2003) of participants involved in the youth leadership program of a state organization serving as an affiliate for America's Promise. The organization employed adult leaders who were placed within communities to promote leadership development among youth organizations. During their year of service, each adult leader provided leadership development training for youth using a nationally juried 4-H curriculum (i.e., Step Up to Leadership). Youth were recruited from local youth-serving organizations (i.e., community agencies, faith-based institutions, and schools). All youth who completed surveys administered at the beginning and end of the study were included in the study. Youth took a lead in organizing community service projects as a culminating activity of their leadership development training. Those projects included, but were not limited to, cleaning local parks, volunteering at homeless shelters, tutoring elementary students as well as serving on community-based and statewide youth advisory councils.

A total of 164 youth representing 22 communities participated in this study. Fiftyfive percent were females. The ethnic background of the participants was comprised of approximately 79\% Caucasian/European American, 7\% African American, 4\% Hispanic American, 2\% Asian American, 1\% Native American, and $7 \%$ who classified themselves as "other." While $58 \%$ indicated they have 
volunteered to serve their community in some capacity, approximately $33 \%$ were never engaged in any community-based volunteer efforts (see Table 2).

Table 2

Frequency and Demographics of Participants in the Study $(\mathrm{N}=164)$

Demographic Variable $\quad$ Frequency Percent

\begin{tabular}{lcc}
\hline Gender & & \\
Female & 90 & 55 \\
Male & 73 & 45 \\
& & \\
Ethnicity & 4 & 2.5 \\
Asian American & 12 & 7.3 \\
Black/African American & 129 & 79.1 \\
Caucasian/European American & 6 & 3.7 \\
Hispanic American & 1 & 0.6 \\
Native American & 11 & 6.8 \\
Other & & \\
& 95 & 58.0 \\
Served as a Volunteer in Community & 54 & 32.9 \\
Yes & 15 & 9.1 \\
No & & \\
No Response &
\end{tabular}

\section{Methods}

The researcher utilized an instrument that was developed for use with a similar study. The instrument consisted of items to assess demographic variables along with the following attitudinal constructs: youth leadership and decision-making (19 questions); youth relationships with adults (eight questions). All items were on a five-point Likert-type scale with one being Strongly Disagree and five being Strongly Agree. Validity was established using a panel of experts. A previous pilot test was conducted with 4-H youth involved in similar community-based service projects. The pilot test conducted using the instrument yielded consistent reliability coefficients. A post-hoc reliability analysis was also conducted where the results revealed the following alpha coefficients for the constructs: youth leadership and decision-making (.90); youth relationships with adults (.88).

The adult leaders trained youth using the Step Up to Leadership curriculum (National 4-H Cooperative Curriculum System Inc., 2003) which presents critical life skills that are pertinent to developing youth leadership. The Step Up to Leadership curriculum's mentor guide provides adult leaders with age appropriate 
activities for youth within various ages and stages. The curriculum's facilitator guide also helps explain how facilitators should prepare for the sessions, note essential concepts of leadership, and present topics that are relevant through leadership activities.

Survey data were collected during the first meeting between the adult leader and the youth. Data were also collected from the same participants after the community projects were completed. Those youth participants who did not complete the post survey were removed from the analysis. A total of 164 individuals gave complete information. Data were analyzed using frequencies, means, and percentages. Paired and independent $t$-tests were used to compare perceptions. Adult leaders administered the questionnaire by following a specific script and instructions provided by the researcher. The survey was administered to participants with the assurance of confidentiality. The Internal Review Board approved the policy that passive consent of parents was permitted before students could participate. Students placed completed surveys in an envelope which was sealed and mailed to the researcher.

\section{Results}

First, prevalence of youth participation was examined in terms of age, gender, ethnicity, and volunteer efforts. Mean scores were computed for each of the attitudinal constructs, thus creating separate index variables for perceptions toward the role of youth leadership and decision-making and perceptions toward youth relationships with adults. A paired $t$-test was used to determine significant differences in youth perceptions of the constructs before engaging in this study and upon completion. As shown in Table 3, youth had significantly more positive perceptions of how youth leadership and decision-making was viewed in their community after their involvement in this project (3.48 pre-survey $\underline{\mathrm{v}}$. 3.76 on post survey). When assessing perceptions of relationships with adults, youth also became more positive towards working with adults (3.41 pre-survey $\underline{\mathrm{v}}$. 3.68 post survey). 
Table 3

Perceptions toward Youth Leadership and Youth-Adult Relationships

\begin{tabular}{|l|c|c|c|c|c|c|}
\hline \multicolumn{7}{|c|}{ Perceptions toward Role of Youth Leadership and Decision-Making } \\
\hline Group & $\mathrm{n}$ & Mean & S.D. & $\mathrm{t}$ & $\mathrm{df}$ & $\mathrm{p}$ \\
\hline Pre-survey & 133 & 3.48 & .59 & 4.73 & 132 & $.00^{*}$ \\
\hline Post survey & 133 & 3.76 & .61 & 3.81 & 146 & $.00^{*}$ \\
\hline \multicolumn{7}{|c|}{ Perceptions of Youth Relationship with Adults } \\
\hline Group & $\mathrm{n}$ & \multicolumn{1}{c|}{ Mean } & S.D. & $\mathrm{T}$ & $\mathrm{df}$ & $\mathrm{p}$ \\
\hline Pre-survey & 147 & 3.41 & .76 & 4.73 & 132 & $.00^{*}$ \\
\hline Post survey & 147 & 3.68 & .72 & 3.81 & 146 & $.00^{*}$ \\
\hline
\end{tabular}

Note. $*=p<.001$

Additional analyses were conducted to make comparisons based on gender. As shown in Table 4, both female and male participants had positive perceptions toward the role of youth leadership and decision-making in their community. However, females were significantly more positive than males on the pre-survey (3.55 ‥ 3.32). Although not significant, females also had more positive perceptions on the post survey (3.80 v. 3.69). It is interesting to note that although females were more positive, males had a much larger gain between the pre-survey and post survey scores.

Table 4

Perceptions Youth by Gender

\begin{tabular}{|c|c|c|c|c|c|c|}
\hline \multicolumn{7}{|c|}{ Perceptions toward the Role of Youth Leadership and Decision-Making } \\
\hline Group & $\mathrm{n}$ & Mean & S.D. & $\mathrm{t}$ & $\mathrm{df}$ & $\mathrm{p}$ \\
\hline \multicolumn{7}{|l|}{ Pre-survey } \\
\hline Females & 85 & 3.55 & .63 & 2.17 & 147 & $.03 *$ \\
\hline Males & 64 & 3.32 & .62 & & & \\
\hline \multicolumn{7}{|l|}{ Post survey } \\
\hline Females & 74 & 3.80 & .63 & 1.02 & 135 & .30 \\
\hline Males & 63 & 3.69 & .58 & & & \\
\hline \multicolumn{7}{|c|}{ Perceptions of Youth Relationship with Adults } \\
\hline \multicolumn{7}{|l|}{ Pre-survey } \\
\hline Females & 86 & 3.45 & .79 & 1.32 & 151 & .18 \\
\hline Males & 67 & 3.28 & .79 & & & \\
\hline \multicolumn{7}{|l|}{ Post survey } \\
\hline Females & 82 & 3.69 & .74 & .23 & 147 & .81 \\
\hline Males & 67 & 3.66 & 67 & & & \\
\hline
\end{tabular}

Note: $*=\mathrm{p}<.05$

In addition to the gender comparisons based on perceptions toward youth leadership, independent t-tests were computed to determine significant differences between females and males based on their perceptions of their relationship with 
adults (see Table 4). Regardless of whether they were females or males, the post survey reflected that they were more positive at the end of the study. As the mean scores indicated that females had a tendency to be more positive than males, no statistical significance was found.

Independent $t$-test analyses using data gathered at the beginning of the study compared those youth who volunteer or engage in some form of community service at least one hour per week to those who do not volunteer at all (see Table 5). Youth who volunteered were significantly more positive (3.67) toward the role of youth leadership and decision-making in communities than those youth who never volunteered (3.06).

Table 5

Youth Perceptions based on Level of Volunteer Participation

\begin{tabular}{|l|c|c|c|c|c|c|}
\hline \multicolumn{6}{|c|}{ Perceptions toward Role of Youth Leadership and Decision-Making } \\
\hline & $\mathrm{n}$ & Mean & S.D. & $\mathrm{t}$ & $\mathrm{df}$ & $\mathrm{p}$ \\
\hline Non-Volunteers & 54 & 3.06 & .69 & 5.49 & 140 & $.00^{*}$ \\
\hline Volunteers & 95 & 3.67 & .49 & & & \\
\hline \multicolumn{7}{|c|}{ Perceptions of Youth Relationship with Adults } \\
\hline Non-volunteers & 54 & 2.87 & .85 & 6.12 & 75.11 & $.00^{*}$ \\
\hline Volunteers & 95 & 3.67 & .55 & & & \\
\hline & & & & & & \\
\hline & & & & & & \\
\hline & & & & & & \\
\hline
\end{tabular}

Note: $* \mathrm{p}<.001$

Table 5 also provides pre-survey data on the comparison between those youth who volunteer and those who do not and their perceptions toward their relationships with adults. When comparing those non-volunteer youth participants to volunteers based on perceptions of their relationships with adults, youth who volunteered were significantly more positive than non-volunteers (3.67 ‥ 2.87). No post survey data were analyzed, for at that stage in the project, all youth were considered as having volunteer experience. 
Table 6

Perception of Non-Volunteering Youth

\begin{tabular}{|l|c|c|c|c|c|c|}
\hline \multicolumn{7}{|c|}{ Perceptions toward Role of Youth Leadership and Decision-Making } \\
\hline & $\mathrm{n}$ & Mean & S.D. & $\mathrm{t}$ & $\mathrm{df}$ & $\mathrm{p}$ \\
\hline Pre-survey & 54 & 3.14 & .61 & 3.83 & 43 & $.00^{*}$ \\
\hline Post survey & 54 & 3.63 & .62 & & & \\
\hline \multicolumn{7}{|c|}{ Perceptions of Youth Relationships with Adults } \\
\hline Pre-survey & 54 & 2.95 & .80 & 5.07 & 48 & $.00^{*}$ \\
\hline Post survey & 54 & 3.58 & .61 & & & \\
\hline
\end{tabular}

Note: $* \mathrm{p}<.001$

Paired $t$-tests were used to determine any significant differences among the perceptions of non-volunteering youth and their leadership in the community and their relationships with adults before and after the study took place. There were significant differences between the pre and post surveys (see Table 6). Youth who had not served as volunteers developed more positive perceptions of youth leadership and decision-making within communities (Pre-survey of $3.14 \underline{\mathrm{v}}$. 3.63 post survey) and relationships with adults (2.95 on pre-survey $\underline{\mathrm{v}} .3 .58$ post survey). Although those youth who did serve as volunteers prior to this study became slightly more positive on the post survey than what was revealed by the pre-survey, there was no statistically significant difference.

\section{Discussion}

This study provides support in the relevance of employing all sources of leadership within communities. Young people are most often seen as being in need of assistance rather than actually being able to assist in community problems. The results provide evidence congruent with other findings which reveal how youth can serve in leadership capacities if they are given ample opportunities to build upon their leadership.

Three major assumptions guided this current investigation. First, it was assumed that participants had formed perceptions about the role of youth and youth-adult relationships in their communities. Although the emphasis of this study explored perceptions of youth in communities, youth leadership was the phenomenon of particular interest. Second, because youth participated within these youth organizations on a voluntary basis, their responses were assumed to reflect their true perceptions and feelings. Third, adult leaders that worked with the youth, who upon being trained to work with youth themselves, were assumed to have adequate skills in effectively recruiting and nurturing youth with leadership potential. 
The results of this study are consistent with prior research revealing the benefits of youth being engaged in leadership development opportunities. Perceptions of the youth became significantly more positive toward youth leadership and decision-making in their communities. This is consistent with the scholarship of experiential learning which stresses that the ideal learner is actively engaged in a quality learning process (Dewey, 1938; Kolb, 1984; Smith, 1991). This further confirms what Mezirow (1997) described as transformative learning which encouraged youth in this study to change their frame of reference by reflecting on more positive attitudes.

Youth also developed more positive perceptions of adults. This is quintessential if individuals and agencies are going to provide youth with the positive experience that is tantamount to their attaining a healthy, constructive adult life. With affirming relationships being the center of positive youth development, young people must feel a strong connection with adults and their community if they are to inculcate the skills needed to serve in leadership roles. Research has suggested that focusing on intergenerational experiences where youth and adults interact and share common goals help reduce negative attitudes that can dishearten the ability to nurture youth leadership (Jones, 2006; Piquart, Wenzel, \& Sorenson, 2000).

Based on gender comparisons, females were more positive than males when examining both constructs. Similar accounts have been prevalent among research studies as well as programs where practitioners are challenged with engaging males. Youth service providers must be strategic in providing opportunities that stimulate and maintain the interest of males. In contrast to many youth programs that are dominated by female participation, these programs were nearly proportionate. Regardless of gender, all youth indicated more positive perceptions over the course of the program. It is also noteworthy to recognize that males had a more significant increase towards positive perceptions when examining the presurvey and post survey scores. Hence, youth service providers should consider involving more males in leadership-based experiential learning endeavors. If the goal is to reach their potential, then merely teaching leadership to most youth may not be enough. They should be afforded the chance to put into practice the skills they have acquired.

The findings also revealed a significant difference between the youth who had not previously served as volunteers in their community and those youth who had served as volunteers. Youth who had volunteer experience were more positive towards the role of youth leadership in their communities as well as their perceptions toward relationships with adults. An analysis was conducted to examine the pre-survey data only because the researcher aimed to minimize the influence the experiences of participating in the project would have on their perceptions. However, the pre- and post survey results from a paired $t$-test did reveal that those youth who had not volunteered developed more positive 
perceptions. These findings suggest that youth should be encouraged to participate in non-traditional volunteer efforts in order to provide various interrelated outcomes including positive social relationships and improved feelings of intrinsic leadership abilities (Harvard Family Research Project, 2008).

Participants in the communities, who were a part of this project, were purposefully selected as a sample of convenience. These groups were predominately limited to youth who had access to plausible youth serving programs. Therefore, a limitation of this study is that the generalizability of the results does not extend beyond these participants and groups. Based on the sample size of this study, the researcher was also limited in the use of appropriate inferential statistics.

\section{Conclusion}

It is concluded that much of this study's value relates to experiential learning techniques, which, in turn, can serve as a central medium for leadership development among young people. This form of training also played a part in strengthening leadership capacity, as related to the practical skills of the youth. Although the study revealed that perceptions can change towards the affirmative when youth have an opportunity to become civically engaged, there was also evidence that experiential learning can serve a role in developing a solid foundation for building leadership skills among young people.

Practical experiences must be considered when nurturing youth leaders while also giving adults the chance to exert their abilities by serving as allies. Young people are indeed an asset to the communities in which they live. However, in order to put forth efforts that attain impact, they must have access to opportunities as well as the relevant information that provides insight on how they can become change agents. While youth-serving organizations continue striving to achieve positive developmental outcomes, there must be research-based models of application available to aid in the enhancement of community youth programs.

\section{Recommendations for Further Research}

The completion of this study presents opportunities for additional research such as:

- Replicating this study with a larger randomized sample to validate the methodology and findings,

- Conducting a longitudinal study to enrich the data to further determine how programmatic improvements can be implemented, 
- Utilizing these findings to assess the quality of youth-adult relationships within a program or project as a measure of quality,

- Assessing the specific leadership and life skills young people acquire while engaged in similar program experiences,

- Conducting a parallel study to compare the prior leadership experiences of youth with their perceived benefits of the program, as well as a selfassessment of their own leadership abilities, and

- Incorporating a control group design to see if training made a difference independent of experiential learning projects. 


\section{References}

America's Promise (2006). Every child, every promise: Turning failure into action. Washington, DC: America's Promise.

Blythe, D. A., \& Leffert, N. (1995). Communities as contexts for adolescent development: An empirical analysis. Journal of Adolescent Research, 10 (1), 64-87.

Camino, L. A. (2000). Youth-adult partnerships: Entering new territory in community work and research. Applied Developmental Science, 4, 11-20.

Camino, L. A. (2001). Evaluation as a tool in community building: Perspectives on the role of youth. Paper presented at the American Evaluation Association Annual Meeting, St. Louis, MO.

Cargo, M., Grams, G. D., Ottoson, J. M., Ward, P., \& Green, L. W. (2003). Empowerment as fostering positive youth development and citizenship. American Journal of Health Behavior, 27, 66-79.

Case Foundation (2006). Citizens at the center: A new approach to civic engagement. Washington, DC: Case Foundation.

Carnegie Council on Adolescent Development. (1992). A matter of time: Risk and opportunity in the non-school hours. New York, NY: Carnegie Corporation of New York.

Checkoway, B., Richards-Schuster, K., Abdullah, S., Aragon, M., Facio, E., Figueroa, L., Reddy, E., Welsh, M., \& White, A. (2003). Young people as competent citizens. Community Development Journal, 28, 298-309.

Creswell, J. (2003). Research Design (2 ${ }^{\text {nd }}$ ed.). Thousand Oaks, CA: Sage.

Dewey, J. (1938). Experience and education. New York: Touchstone.

Eccles, J. S., \& Gootman, J. A. (Eds.). (2002). Community programs to promote youth development. Committee on Community-Level Programs for Youth. Washington, DC: National Academy Press.

Flanagan, C. A. (1998). Exploring American character in the sixties generation. In A. Colby, J. James, \& D. Hart (Eds.), Competence and character through life (pp. 169-185). Chicago: University of Chicago Press. 
Flanagan, C. A., \& Van Horn, B. (2003). Youth civic development: A logical next step in community youth development. In F. Villarruel, D. Perkins, L. Borden, \& J. Keith (Eds.), Community Youth Development: Programs policies and practices (pp 273-296). Thousand Oaks: Sage Publications.

Hughes, D. M., \& Curnan, S. P. (2000, winter). Community youth development: A framework for action. CYD Journal, 1, 7-13.

Israel, G. D., \& Ilvento, T. W. (1995, April). Everybody wins: Involving youth in community needs assessment. Journal of Extension, 33. Available online at: http://www.joe.org/joe/1995april/al.html

Harvard Family Research Project (2008). After school programs in the $21^{\text {st }}$ century: Their potential and what it takes to achieve it. A report on issues and opportunities in out-of-school time evaluation (Issue No. 10). Cambridge, MA: Harvard Graduate School of Education

Jones, K. R., \& Perkins, D. F. (2006). Youth and adult perceptions of their relationships within community-based youth programs. Youth \& Society, 38 (1), 90-109.

Jones, K. R. (2006). Relationships matter: A mixed methods evaluation of youth and adults working together as partners. Journal of Youth Development, 1(2). http://www.nae4ha.org/directory/jyd/current_issue.aspx

Kaplan, M. (1997). The benefits of intergenerational community service projects: Implications for promoting intergenerational unity, community activism, and cultural continuity. In K. Brabazon, \& R. Disch (Eds.), Intergenerational approaches for aging: Implications for education, policy and practice (pp. 211-228), New York, NY: The Haworth Press.

Kolb, D. A. (1984). Experiential learning: Experience as the source of learning and development. Englewood Cliffs, NJ: Prentice Hall.

Kress, C. (2004). Essential elements of 4-H youth development. Available online at: http://www.national4- headquarters.gov/library/elements.ppt

Larson, R., Walker, K., \& Pearce, N. (2005). Youth-driven vs. adult-driven youth development programs: Contrasting models of youth-adult relationships. Journal of Community Psychology, 33 (1), 57-74.

Lerner, R. M. (2007). The good teen: Rescuing adolescence from the myths of the storm and stress years. New York: Crown Publishers. 
Lerner, R. M. (2004). Liberty: Thriving and civic engagement among America's youth. Thousand Oaks, CA: Sage Publications.

Lerner, R. M. (1995). America's youth in crisis: Challenges and options for programs and policies. Thousand Oaks, CA: Sage.

Lerner, R. M., Dowling, E. M., \& Anderson, P. M. (2003). Positive youth development: Thriving as the basis of personhood and civil society. Applied Developmental Science, 7, 172-180.

Libby, M., Rosen, M., \& Sedonaen, M. (2005). Building youth-adult partnerships for community change: Lessons from the Youth Leadership Institute. Journal of Community Psychology, 33 (1), 111-120.

Marcelo, K., Lopez, M., \& Kirby, E. (2007). Civic engagement among minority youth. University of Maryland, College Park, MD: Center for Information and Research on Civic Learning and Engagement.

Mezirow, J. (1997, Summer). Transformative learning: Theory to practice. In P. Cranton (Ed.), Transformative learning in action: Insights from practice. New directions for adult and continuing education, 74, 5-12, San Francisco: Jossey-Bass.

National 4-H Cooperative Curriculum System, Inc. (2003). Step up to leadership. Available online at: www.n4hccs.org

Pancer, S. M., Rose-Krasnor, L., \& Loiselle, L. D. (2002). Youth conferences as a context for engagement. New Directions for Youth Development, 96, 4764.

Perkins, D. F., \& Borden, L. M. (2003). Positive behaviors, problem behaviors and resiliency in adolescence. In R. M. Lerner, M. A. Easterbrooks, \& J. Mistry (Vol. Eds.), Handbook of Psychology: Vol. 6. Developmental Psychology (pp. 373-394). New York: John Wiley \& Sons.

Perkins, D., Borden, L., \& Villarruel, F. (2001). Community youth development: A partnership for action. School Community Journal, 11, 39-56.

Pinquart, M., Wenzel, S., \& Sorensen, S. (2000). Changes in attitudes among children and elderly adults in intergenerational group work. Educational Gerontology, 26, 523-540. 
Pittman, K. J. (2000, March). Grantmaker strategies for assessing the quality of unevaluated programs and the impact of unevaluated grantmaking. Paper presented at the Evaluation of Youth Programs symposium at the Biennial Meeting of the Society for Research on Adolescence, Chicago.

Pittman, K., Irby, M., \& Ferber, T. (2000). Unfinished business: Further reflections on a decade of promoting youth development. In P. L. Benson and K. J. Pittman (Eds.), Trends in youth development: Visions, realities and challenges. Norwell, MA: Kluwer Academic Publishers.

Sandefur R. L., \& Laumann, E. O. (1998). A paradigm for social capital. In Rationality and Society. Thousand Oaks, CA: Sage.

Search Institute (1997). 40 developmental assets. Available online at www.search-institute.org

Smith, R. M. (1991, April). How people become effective learners. Adult Learning, 2, 11-13.

Youniss, J., McLellan, J. A., \& Yates, M. (1997). What we know about engendering civic identity. American Behavioral Scientist, 40, 620-631.

Villarruel, F. A., \& Lerner, R. M. (Eds.) (1994). Promoting community-based programs for socialization and learning. New Directions for Child Development, 63. San Francisco: Jossey-Bass.

Zeldin, S., McDaniel, A., Topitzes, D., \& Calvert, M. (2000). Youth in decisionmaking: A study on the impact of youth on adults and organizations. A report developed by The University of Wisconsin-Madison and the Innovation Center for Community and Youth Development: Chevy Chase, MD. 


\section{Biography}

Dr. Kenneth Jones is an assistant professor in the Department of Community and Leadership Development at the University of Kentucky. He is also an extension specialist, supporting county agents with youth program responsibilities through professional development trainings. His research interests include the influence of community-based youth-adult relationships on youth leadership and the effect peer mentoring has on student leadership within school settings. 